\title{
GROWTH AND AGE ESTIMATION OF THE GREATER FORKBEARD, PHYCIS BLENNOIDES (ACTINOPTERYGII: GADIFORMES: PHYCIDAE), FROM THE GULF OF TUNIS (CENTRAL MEDITERRANEAN)
}

\author{
Ahlem ROMDHANI ${ }^{1,2 *}$, Mohamed-Hédi KTARI ${ }^{1}$, Jean-Louis DUFOUR ${ }^{2}$, Kélig MAHE ${ }^{2}$, \\ and Patrice FRANCOUR ${ }^{3}$ \\ ${ }^{1}$ Laboratoire de biologie et biodiversité des populations, Faculté des sciences, Campus universitaire El Manar II, \\ Tunis, Tunisia \\ ${ }^{2}$ Institut Français de Recherche pour l'exploitation de la mer (IFREMER), Boulogne-sur-Mer, France \\ ${ }^{3}$ Université Nice Sophia Antipolis, CNRS, ECOMERS, Nice, France
}

\begin{abstract}
Romdhani A., Ktari M.-H., Dufour J.-L., Mahe K., Francour P. 2016. Growth and age estimation of the greater forkbeard, Phycis blennoides (Actinopterygii: Gadiformes: Phycidae), from the Gulf of Tunis (central Mediterranean). Acta Ichthyol. Piscat. 46 (1): 25-32.
\end{abstract}

Background. The greater forkbeard, Phycis blennoides (Brünnich, 1768), is a gadiform species, which has economical value and its population is dwelling in a $60-800 \mathrm{~m}$ depth range throughout the Atlantic and the Mediterranean. Along African north coast, there is a lack of information about the biology (age, growth, sex-ratio) of this species. This study provides the first data on population parameters of $P$. blennoides in Tunisia.

Materials and methods. Specimens of Phycis blennoides were collected from the landings of the artisanal fisheries between September 2007 and June 2010. The length-weight relations were determined according to the allometric equation: $W=a \mathrm{TL}^{b}$. Growth parameters were estimated using the von Bertalanffy growth equation. Results. Length (TL)-weight $(W)$ relations were allometrically positive for the females $\left(W=22.10^{-4} \mathrm{TL}^{3.409}\right)$, males $\left(W=13.10^{-4} \mathrm{TL}^{3.674}\right)$, and both sexes $\left(W=19.10^{-4} \mathrm{TL}^{3.460}\right)$, without significant differences between males and females. The relation between otolith weight and age showed a significant difference between males and females. The growth parameters were calculated as $\mathrm{TL}_{\infty}=57.17 \mathrm{~cm}, K=0.193 \cdot$ year $^{-1}, t_{0}=-1.578 \cdot$ year for the females, and $44.74 \mathrm{~cm}, 0.313 \cdot$ year $^{-1}$, and $-1.210 \cdot$ year for the males, respectively. The females grew faster than the males which did not exceed $45 \mathrm{~cm}$. The growth performance index $\Phi^{\prime}$ calculated for the females $(2.80 \mathrm{~cm}$. year $\left.{ }^{-1}\right)$ and males $\left(2.79 \mathrm{~cm} \cdot\right.$ year $\left.^{-1}\right)$ yielded similar results.

Conclusion. Results reported in this work will contribute to the knowledge on the biology of P. blennoides in Tunisia, with the aim of generating sufficient information to improve future stock management and sustainable fisheries.

Keywords: otolith, biological traits, length-weight relation, von Bertalanffy growth function

\section{INTRODUCTION}

The greater forkbeard, Phycis blennoides (Brünnich, 1768), occurs throughout the Mediterranean, Black Sea, Adriatic Sea, and Atlantic Ocean, from Iceland to Cap Blanc, and in the Faeroe Islands, Madeira, and the Azores Islands (Whitehead et al. 1986, Fischer et al. 1987, Cohen et al. 1990). This gadiform fish is found along the continental shelf and the slope, on the bottoms from 60 to $800 \mathrm{~m}$ depth (Cohen et al. 1990, Campillo 1992, Quéro et al. 2003) but reaches the depth of $1100 \mathrm{~m}$ in the eastern Adriatic (Pallaoro and Jardas 2002), and $1200 \mathrm{~m}$ in the Catalan Sea (Stefanescu unpublished ${ }^{* *}$ ).
Bouhlel (1979) showed that Phycis blennoides has a wide distribution along the northern-, eastern-, and southern Tunisian coasts. Its abundance decreases from the north east, to become rare in southern Tunisia. The greater forkbeard is recorded between 60 and $436 \mathrm{~m}$ depth in the north, while the maximum depth increases in the south, reaching $700 \mathrm{~m}$ (Bouhlel 1979).

Several aspects of biology of Phycis blennoides have already been studied: the feeding habits in the Bay of Biscay (Sorbe 1977), Gulf of Valencia (Morte et al. 2002), Island of Kastellorizo (Papaconstantinou and Caragistou 1989), northern Tyrrhenian (Sartor and Biagi 1992, Sartor

* Correspondence: Dr. Ahlem Romdhani, Laboratoire de biologie et biodiversité des populations, Faculté des sciences Tunis, Campus Universitaire El Manar II, 2092, Tunis, Tunisie, phone and fax:+216971933 03, e-mail: (AR) romdhani.ahlem@gmail.com,(MHK) mohamedhedi.ktari@yahoo.fr,(JLD)jean.louis.dufour@ifremer.fr, (KM) kelig.mahe@ifremer.fr, (PF)francour@unice.fr.

** Stefanescu C.B. 1991. Comunidades ictiologicas demersales del Mar Catalan (Mediterraneo Nord occidental) por debajo de los $1000 \mathrm{~m}$ de profundidad. University of Barcelona, $\mathrm{PhD}$ Thesis. 
et al. 1993), and Azores Islands (Morato et al. 1999); the weight-length relations in the Mediterranean Balearic Islands and Spanish coasts (Morey et al. 2003), in the north of Aegean Sea (Filiz and Bilge 2004, Karakulak et al. 2006), the west coast of Portugal (Mendes et al. 2004), and Adriatic Sea (Dulčić and Kraljević 1996); age and growth in the Iberian Peninsula (Casas and Piñeiro 2000), and in the north-western Mediterranean (GallardoCabello 1986a, 1986b); and the reproductive biology in the western Mediterranean (Gallardo-Cabello and GualFrau 1984, Rotllant et al. 2002), north-western Ionian Sea (Matarrese et al. 1998), and in Algeria (Benghali et al. 2014). On the Tunisian coast, the biology of this species remains largely unknown.

The objective of this study was to provide some information on the age and growth of Phycis blennoides in Tunisia with the aim to provide information for management and sustainable fishery of this species.

\section{MATERIALS AND METHODS}

A total of 496 individuals were collected monthly between September 2007 and June 2010 from the artisanal fishing (Tunis harbour; fishing gears and depth unknown). In the laboratory, total length (TL) [cm], and the total weight $(W)[\mathrm{g}]$ were measured for each specimen. The length-weight relation was described by the equation (Le Cren 1951, Froese et al. 2011):

$$
W=a \mathrm{TL}^{b}
$$

where $W$ is the total weight, TL is the total length, $a$ is the coefficient related to body form, and $b$ is an exponent indicating isometric growth when equal to 3 and allometric growth when different from 3 (the allometry is positive if $b>3$ and negative if $b<3$ ) (Froese 2006). The comparison of slopes and intercepts of regression lines of the lengthweight relation was sought by a covariance analysis (ANCOVA) (Zar 1999).

To estimate the age, the sagittal otoliths were removed from the cranial cavity. Then, they were cleaned, dried, weighed ( $W_{\mathrm{o}}$, precision $0.001 \mathrm{mg}$ ), and stored in paper envelopes. Otoliths of Phycis blennoides are opaque and too thick to allow direct reading of the rings of growth, and thin transversal sections of the otoliths through the core (nucleus) were necessary. Whole sections were viewed under a binocular magnifying glass, connected to a digital camera coupled to a computer equipped with software with image processing TNPC (digital processing of the calcified pieces - a software developed by IFREMER*). The observation of annuli was carried out under reflected light. During the reading, the alternations of opaque and translucent zones were checked by two readers. To validate the periodicity of increment formation, marginal-increment analysis was

\footnotetext{
${ }^{*}$ www.tnpc.fr

${ }^{* *}$ http://www.r-project.org

${ }_{* * *}^{*}$ http://sourceforge.net/projects/tinn-r
}

carried out on otoliths by calculating marginal increment (MI) according to this following formula:

$$
\mathrm{MI}=\left(R-r_{n}\right) \cdot\left(r_{n}-r_{n-1}\right)^{-1}
$$

where $R$ is otolith radius, $r_{n}$ is the distance between the edge and the last growth ring, and $r_{n-1}$ is the distance between the edge and the second last growth ring. Age was estimated by interpreting growth rings on 409 otoliths.

Age and total length data were used to describe the growth of Phycis blennoides using the von Bertalanffy growth function (VBGF) according to the following formula (Ricker 1975):

$$
\mathrm{TL}_{t}=\mathrm{TL}_{\infty}\left(1-e^{-K\left(t-t_{0}\right)}\right)
$$

where $K$ is the rate at which the asymptote is reached, $\mathrm{TL}_{t}$ is the length at age $t, \mathrm{TL}_{\infty}$ is the asymptotic length, and $t_{0}$ is the theoretical age (in years) at zero length (scaling factor). The value of $t_{0}$ does not have biological significance (Knight 1968). To seek the statistical significance of differences among growth parameters for males and females, a multivariate analysis, the Hotelling $T^{2}$ test (Bernard 1981), was performed.

The fish growth performance was estimated using the index (Pauly and Munro 1984):

$$
\Phi^{\prime}=\log K+2 \cdot \log \left(\mathrm{TL}_{\infty}\right)
$$

This index is preferred for growth comparison rather than comparison of $L_{\infty}$ and $K$ individually, because of the correlation between these two parameters (Sparre 1987).

The determination of the parameters of the model $\left(L_{\infty}\right.$, $K$, and $t_{0}$ ) and all the statistical analyses were conducted using the open-source statistical package $\mathrm{R}^{* *}$ and the text editor $\mathrm{R}^{* * *}$.

\section{RESULTS}

Sampling and length-weight relation. A total of 496 individuals were sampled for this study, 70 were males and 345 females. The sex of the remaining 81 individuals could not be macroscopically determined because they had very thin and translucent immature gonads. These immature individuals ranged in size from 16.0 to $24.2 \mathrm{~cm}$ TL; males ranged from 17.3 to $35.5 \mathrm{~cm}$ TL, females from 16.9 to $47.7 \mathrm{~cm}$ TL (Fig. 1).

As the relative growth is concerned, the statistical analysis indicates a positive allometry for females $\left(W=22.10^{-4} \mathrm{TL}^{3.409}\right)$, males $\left(W=13.10^{-4} \mathrm{TL}^{3.674}\right)$, and for the total sample $\left(W=19.10^{-4} \mathrm{TL}^{3.460}\right)$ (Table 1 ; all $P$-values of the $t$-test $<0.001)$. The weight-length relation showed that there were no significant differences between males and females (ANCOVA, $P=0.151$ ).

Otoliths. Fish total lengths (TL) were significantly correlated with the weights of theright- $\left(W_{\mathrm{o}}=1.64 .10^{-4} \mathrm{TL}^{2.01}\right.$; 
Parameters of the length-weight relations for Phycis blennoides in the Gulf of Tunis

\begin{tabular}{lccccccc}
\hline & $a$ & $b$ & $\mathrm{SE}_{b}$ & $n$ & $r^{2}$ & $P$ & Growth type \\
\hline Males & $13.10^{-4}$ & 3.674 & 0.123 & 70 & 0.908 & 0.00 & $\mathrm{~A}+$ \\
Females & $22.10^{-4}$ & 3.409 & 0.047 & 345 & 0.936 & 0.00 & $\mathrm{~A}+$ \\
Total & $19.10^{-4}$ & 3.460 & 0.045 & 496 & 0.929 & 0.00 & $\mathrm{~A}+$ \\
\hline
\end{tabular}

$a=$ intercept, $b=$ slope, $\mathrm{SE}_{b}=$ standard error of $b, n=$ sample size, $r^{2}=$ coefficient of determination, $P=P$-value of the $t$-test $\left(H_{0} ; b=3\right)$, $\mathrm{A}+=$ positive allometry.

$\left.n=409 ; r^{2}=0.624 ; P<0.05\right)$ and left otolith $\left(W_{\mathrm{o}}=\right.$ $\left.1.61 .10^{-4} \mathrm{TL}^{2.02} ; n=409 ; r^{2}=0.844 ; P<0.05\right)$, and there were no significant differences between right and left otoliths (ANCOVA, $P=0.832$; for the total sample, $W_{0}=$ $1.50 .10^{-4} \mathrm{TL}^{2.26} ; n=818 ; r^{2}=0.702$ ) (Fig. 2).

Age and growth. Opaque and hyaline zones were detectable in the otoliths of both axes, and they were clearest in the dorsal area of the otolith. The majority of the otoliths showed several check rings and double bands in the ventral area (Fig. 3). Marginal increments were

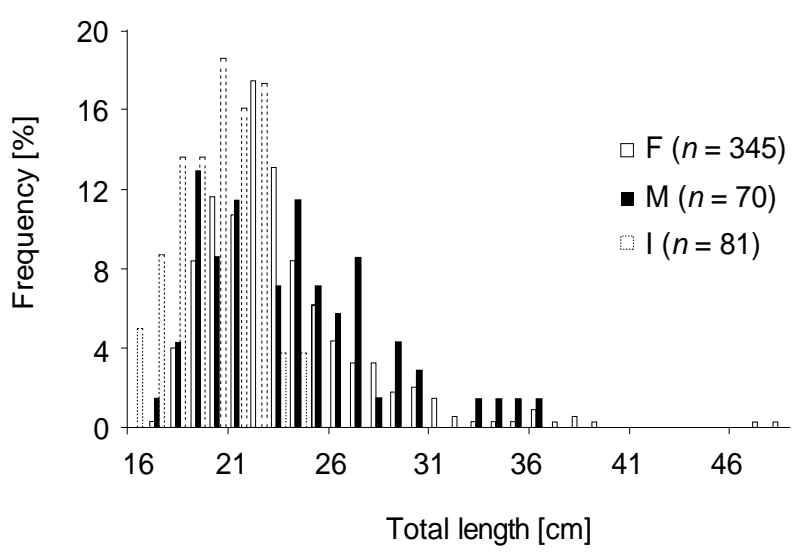

Fig. 1. Length-frequency distribution of males, females, and immature individuals of Phycis blennoides acquired from the Gulf of Tunis

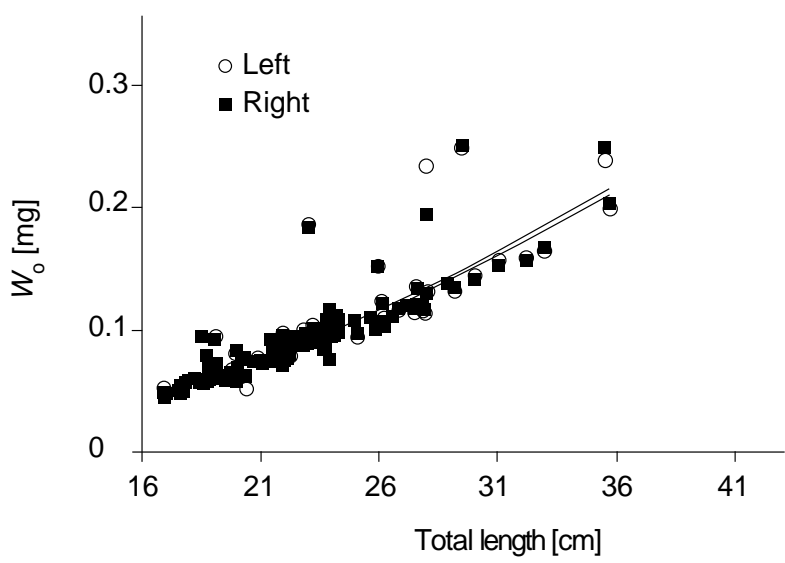

Fig. 2. Linear regression between total length and otolith weight $\left(W_{\mathrm{o}}\right)$ of Phycis blennoides from the Gulf of Tunis measured for males and females. Yearly, only one annulus appeared between August and December (Fig. 4).

The age-length relation was determined from the agelength key (Table 2). Age estimates ranged from 0 to 6 years. Female $(n=342)$ and male $(n=67)$ growth was higher during the first 2 years, until about $37 \mathrm{~cm}$ TL for females and $36 \mathrm{~cm}$ TL for males. The VBGF parameters were calculated as $\mathrm{TL}_{\infty}=57.17 \mathrm{~cm}, K=0.193 \cdot$ year $^{-1}, t_{0}$ $=-1.578 \cdot$ year for females, and respectively $44.74 \mathrm{~cm}$, $0.313 \cdot$ year $^{-1}$, and $-1.210 \cdot$ year for males. The greater forkbeard did not show sexual dimorphism in growth (Hotelling's $T^{2}$ test; $P>0.05$ ). For sex combined, the parameters were $65.73 \mathrm{~cm}, 0.134 \cdot$ year $^{-1}$ and $-2.050 \cdot$ year, respectively. The minimum observed length was $17 \mathrm{~cm}$ $\mathrm{TL}$, corresponding to age 1 group; the maximum length recorded for females (47 cm TL at 3 years) and males (36 cm TL at 2 years). The growth performance index for females $\left(\Phi^{\prime}=2.80 \mathrm{~cm} \cdot\right.$ year $\left.^{-1}\right)$ was similar to the value calculated for males $\left(\Phi^{\prime}=2.79 \mathrm{~cm} \cdot\right.$ year $\left.^{-1}\right)$; for both sexes, the index of growth was $2.76 \mathrm{~cm} \cdot$ year $^{-1}$.

Age $-W_{0}$ relation. The relations between otolith weight $\left(W_{\mathrm{o}}\right)$ and age were significantly different between males $\left(W_{\mathrm{o}}=-0.0846+0.2616\right.$ Age; $\left.r^{2}=0.832\right)$ and females $\left(W_{\mathrm{o}}^{\mathrm{o}}=0.011+0.1718\right.$ Age $\left.; r^{2}=0.869\right)$ (ANCOVA, $P=$ $0.008)$. The otolith weight of males grew then faster than that of females (Fig. 5).

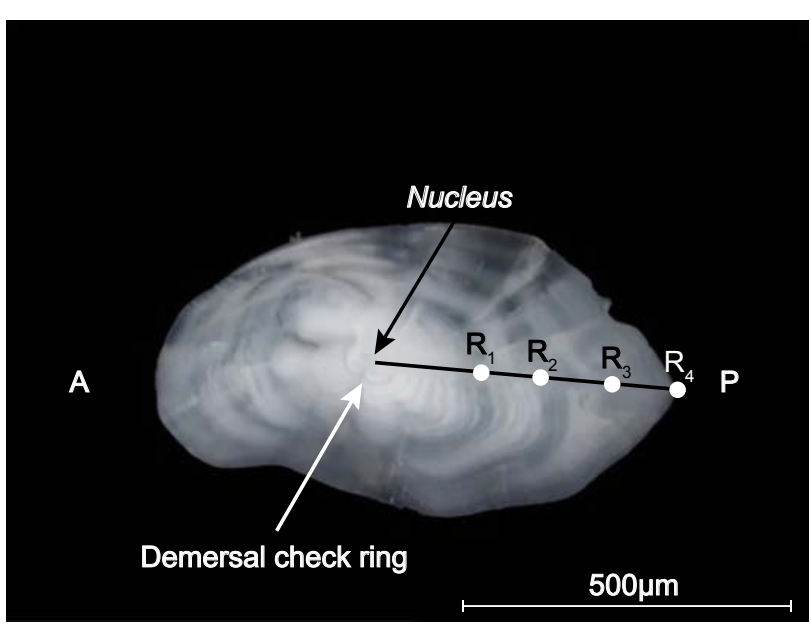

Fig. 3. Otolith section from a four-year old specimen of Phycis blennoides from the Gulf of Tunis, showing the demersal check and the annual rings (R1, R2, R3, R4); $\mathrm{A}=$ anterior, $\mathrm{P}=$ posterior 

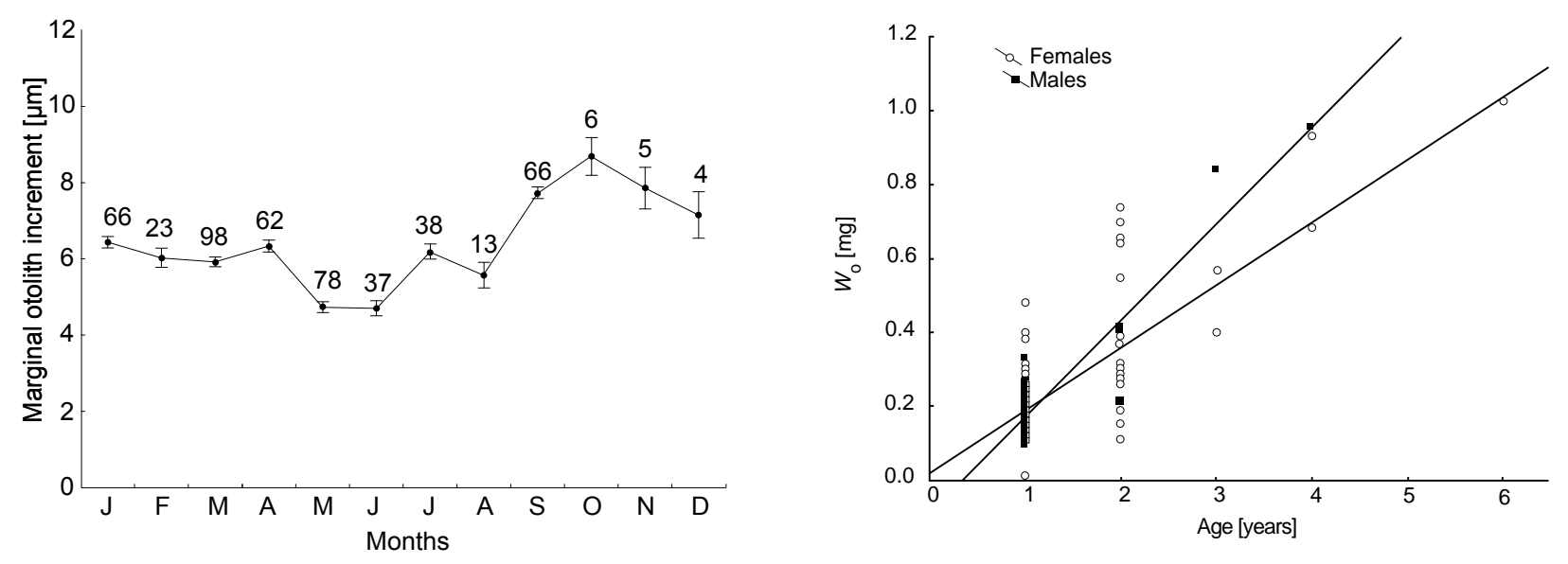

Fig. 4. Mean monthly marginal increments ( \pm standard Fig. 5. Relation between the otolith weight $\left(W_{\mathrm{o}}\right)$ and the age error of the mean) of otoliths of Phycis blennoides of the Gulf of Tunis of Phycis blennoides from the Gulf of Tunis

Table 2

Length frequency of individual length classes, age groups, and sexes of Phycis blennoides from the Gulf of Tunis

\begin{tabular}{|c|c|c|c|c|c|c|c|c|c|c|c|c|}
\hline & \multicolumn{12}{|c|}{ Number of fish } \\
\hline & \multicolumn{2}{|c|}{0} & \multicolumn{2}{|c|}{1} & \multicolumn{2}{|c|}{2} & \multicolumn{2}{|c|}{3} & \multicolumn{2}{|c|}{4} & \multicolumn{2}{|c|}{6} \\
\hline & $\mathrm{F}$ & $\mathrm{M}$ & $\mathrm{F}$ & M & $\mathrm{F}$ & M & $\mathrm{F}$ & M & $\mathrm{F}$ & M & $\mathrm{F}$ & M \\
\hline \multicolumn{13}{|l|}{ Length $[\mathrm{cm}]$} \\
\hline 16 & & & & & & & & & & & & \\
\hline 17 & & & 1 & 1 & & & & & & & & \\
\hline 18 & 1 & & 13 & 3 & & & & & & & & \\
\hline 19 & & & 29 & 9 & & & & & & & & \\
\hline 20 & 3 & & 37 & 6 & & & & & & & & \\
\hline 21 & 2 & & 35 & 8 & & & & & & & & \\
\hline 22 & 3 & & 57 & 4 & & & & & & & & \\
\hline 23 & & & 44 & 3 & 1 & & & & & & & \\
\hline 24 & 1 & & 25 & 8 & 2 & & & & & & & \\
\hline 25 & & & 18 & 5 & 3 & & & & & & & \\
\hline 26 & & & 12 & 4 & 3 & & & & & & & \\
\hline 27 & & & 7 & 4 & 4 & 2 & & & & & & \\
\hline 28 & & & 8 & 1 & 2 & & 1 & & & & & \\
\hline 29 & & & 5 & 2 & 1 & 1 & & & & & & \\
\hline 30 & & & 5 & & 2 & & & & & 1 & & \\
\hline 31 & & & 3 & 1 & 2 & & & & & & & \\
\hline 32 & & & 2 & & & & & & & & & \\
\hline 33 & & & & 1 & 1 & & & & & & & \\
\hline 34 & & & & & 1 & & & 1 & & & & \\
\hline 35 & & & & & 1 & 1 & & & & & & \\
\hline 36 & & & 1 & & & 1 & 1 & & & & & \\
\hline 37 & & & & & 1 & & & & & & & \\
\hline 38 & & & & & & & & & 1 & & 1 & \\
\hline 39 & & & & & & & & & 1 & & & \\
\hline 47 & & & & & & & 1 & & & & & \\
\hline$m$ & 21 & & 22.62 & 23 & 28.25 & 30.8 & 37 & 34 & 38.5 & 30 & 43 & \\
\hline $\mathrm{SE}_{m}$ & 0.52 & & 0.19 & 0.47 & 0.76 & 1.96 & 5.51 & & 0.5 & & & \\
\hline$n^{m}$ & 10 & & 302 & 60 & 24 & 5 & 3 & 1 & 2 & 1 & 1 & \\
\hline
\end{tabular}

$0,1,2,3,3,5,6=$ individual age groups, $\mathrm{F}=$ female, $\mathrm{M}=$ male, $m=$ mean values of length, $\mathrm{SE}_{m}=$ standard error of $m, n=$ sample size. 


\section{DISCUSSION}

Phycis blennoides is an economically important species as the other Phycidae family members. However, relatively little information is available for P. blennoides length-weight relation and growth parameters in the southern Mediterranean. The weight-length relation parameters for P. blennoides from different areas are given in Table 3. In Tunisia, the slope coefficient varied between 3.41 and 3.67, showing a positive allometry for both males and females. In the studies reported by other authors (Table 3 ), the calculated values of $b$ were generally lower than those in Tunisia (2.78 to 3.27; we did not consider the study of Filiz and Bilge (2004) because of the low number of sampled fish). These lower values can be explained by the smallest $\mathrm{TL}_{\text {min }}: 4$ to 12.3 vs. 16 to 17.3 in Tunisia). In spite of the sampling effort, samples were not representative for the entire population size range (small individuals $<16 \mathrm{~cm}$ TL as well as individuals $>48 \mathrm{~cm}$ TL not sampled), probably as a result of the fishing gear selectivity and the natural scarceness of larger individuals in the population. The parameters of the weight-length relation can be useful as practical index of the condition of fish (Mouine et al. 2010). Changes in fish shape, range of size (juveniles, adults), physiological or biological parameters, and environmental conditions, can all influence the growth exponent $b$ (Bolger and Connolly 1989, Lester et al. 2004, Froese 2006).

Age estimation for Gadiformes presents some difficulties due to otolith thickness, which in most of the species requires special processing methods to allow growth increment reading (Morales-Nin et al. 1998, Deree 1999). The transversal section has also been used to interpret the otoliths of the forkbeard, Phycis phycis (Linnaeus, 1766), which present morphological similarities, namely the thickness, the numerous check rings, and the clearly distinguishable demersal check ring, which, as reported for this species, may be associated with a change in diet and/or environment from a pelagic to a demersal habitat (Matarrese et al. 1998, Costa Abecasis et al. 2009). Sectioning has been considered, in fact, as a suitable technique for gadiform dense otoliths, allowing faster and better study (Carpentier et al. 1991, MoralesNin 1992). Ageing greater forkbeard by interpreting growth increment structures in otoliths appears to be a valid method, since monthly proportion of the marginal increment supports the hypothesis of annual growth increment deposition, with highly dense material being deposited during spring and summer months.

The otolith weight $\left(W_{0}\right)$ is significantly correlated to the fish length and to age. These relations can then allow estimating fish length and fish age from otolith weight. A relation between otolith weight, or dimension, and fish length has been used in identifying prey size from stomach content samples (Ross 2005, Bilge 2013). Such relation may be particularly relevant to age determination of fish, such as Gadiformes - in which otolith structures can be difficult to interpret (Morales-Nin et al. 1998). Because the technique is based solely on measurable parameters (the otolith weight), it may also have advantages over traditional age reading, including an amenability to data processing, standardization of ageing criteria, and avoidance of subjective judgements by the personnel involved (Pawson 1990).

The VBGF parameters estimated in this study for the greater forkbeard, Phycis blennoides, showed a relatively slow growth. The greater forkbeard did not show sexual dimorphism in growth, even though differences in growth between sexes are a common feature among related Phycidae such as Phycis phycis (see Casas and Piñeiro 2000). The estimated $\mathrm{TL}_{\infty}$ for females and males, and for combined sex were 57.17, 44.74, and $65.73 \mathrm{~cm}$, respectively. The $\mathrm{TL}_{\infty}$ and $\mathrm{TL}_{\max }$ reported by other authors for females were greater than those for males and confirm

Table 3

Parameters of the length-weight relation of Phycis blennoides by author and study area

\begin{tabular}{|c|c|c|c|c|c|c|c|c|}
\hline Area & Sex & $n$ & $\begin{array}{l}\mathrm{TL}_{\min } \\
{[\mathrm{cm}]}\end{array}$ & $\begin{array}{l}\mathrm{TL}_{\max } \\
{[\mathrm{cm}]}\end{array}$ & $b$ & $\mathrm{SE}_{b}$ & $r^{2}$ & Reference \\
\hline \multirow[t]{2}{*}{ North Aegean Sea (Greece) } & $\mathrm{T}$ & 505 & 6.4 & 50 & 3.23 & - & 0.97 & Stergiou and Moutopoulos \\
\hline & $\mathrm{T}$ & 532 & 6.4 & 46.4 & 3.19 & - & 0.97 & 2001 \\
\hline North-eastern Atlantic & $\mathrm{T}$ & 178 & - & - & 3.23 & - & - & Pérez and Contreras 1995 \\
\hline Balearic Islands & $\mathrm{T}$ & 343 & 5.5 & 53.8 & 3.27 & - & 0.99 & Merella et al. 1997 \\
\hline Western Mediterranean & $\mathrm{T}$ & 189 & 4 & 42 & 2.97 & 0.215 & 0.96 & Morey et al. 2003 \\
\hline $\begin{array}{l}\text { Northern Aegean Sea } \\
\text { (Turkey) }\end{array}$ & $\mathrm{T}$ & 12 & 12.3 & 15 & 3.55 & - & 0.89 & Filiz and Bilge 2004 \\
\hline Portuguese west coasts & $\mathrm{T}$ & 39 & 17.3 & 55.5 & 2.84 & - & 0.94 & Mendes et al. 2004 \\
\hline \multirow[t]{3}{*}{ Strait of Sicily } & M & - & - & - & $2.81-2.91$ & - & - & Ragonese et al. 2004 \\
\hline & $\mathrm{F}$ & - & - & - & $2.78-2.85$ & - & - & \\
\hline & $\mathrm{T}$ & - & 5 & 54 & - & - & - & \\
\hline Gulf of Cadiz & $\mathrm{T}$ & 51 & 8.6 & 47.8 & 3.01 & - & 0.97 & Torres et al. 2012 \\
\hline \multirow[t]{3}{*}{ Gulf of Tunis } & M & 70 & 17.3 & 35.5 & 3.67 & 0.123 & 0.90 & Presently reported study \\
\hline & $\mathrm{F}$ & 345 & 16.9 & 47.7 & 3.41 & 0.047 & 0.94 & \\
\hline & $\mathrm{T}$ & 496 & 16.0 & 47.7 & 3.46 & 0.045 & 0.93 & \\
\hline
\end{tabular}

$n=$ simple size, $\mathrm{TL}=$ total length (minimum or maximum), $b=$ slope, $\mathrm{SE}_{b}=$ standard error of the slope $b, r^{2}=$ coefficient of determination, $\mathrm{M}=$ males, $\mathrm{F}=$ females, $\mathrm{T}=$ total (both sexes). 
the dimorphism in size (females larger than males), with sex ratios weighted in favour of males as it is frequently reported for gadiforms (see Rotllant et al. 2002). This can be explained because many slope-dwelling fish females become mature when they are reaching their maximum total length and then somatic growth slows down (Gordon et al. 1995). The lengths reported for Tunisia are lesser than those reported by Casas and Piñeiro (2000) or Cohen et al. (1990): $112.7 \mathrm{~cm}\left(\mathrm{TL}_{\infty}\right.$; all samples) and $110 \mathrm{~cm}$ $\left(\mathrm{TL}_{\max }\right)$, respectively. The $L_{\infty}$ estimated for sexes combined $(65.73 \mathrm{~cm})$ is rather in agreement with the asymptotic length reported by Petrakis and Papaconstantinou (1992): $65.8 \mathrm{~cm}$ (Table 4). These variations in asymptotic size are essentially the result of differences in sampling sizes and size composition of populations. In fact, growth model estimates are strongly affected by the lack of very young or old individuals (Mouine-Ouesleti et al. 2015). The maximum age observed in the presently reported study was 6 years. Phycis blennoides of the Gulf of Tunis has a smaller longevity than on the north and northwest of the Iberian Peninsula (Casas and Piñeiro 2000) and on the Strait of Sicily (Fiorentino et al. 2003, Ragonese et al. 2004). Differences observed can be due to the different population size structures or even different fishing pressures in these areas. The absence of 5 years specimens is probably due to the limited sampling of both small and large individuals in the presently reported study. The value of growth performance index $\left(\Phi^{\prime}\right)$ indicates a lower growth in Tunisia than Strait of Sicily and northwest of the Iberian Peninsula (Table 4). Geographic location and some environmental condition, such as the date and time of capture, index of condition, disease and parasites loads can affect age estimates (Bagenal and Tesch 1978).

Study of cross-sectioned otoliths of Phycis blennoides from of the Tunisian coast shows that greater forkbeard grow rapidly during the first two years of life, after which the growth slows down. Fish growth can be influenced by biotic factors related to the genotype or physiological condition of the fish, by abiotic factors, or by a combination of the two. Nothing being known on this issue for P. blennoides; clear conclusions cannot be made regarding the relative importance of environmental and genetic factors on the growth rate variability observed in this study.

The greater forkbeard is a species regularly fished along the coastal areas of the Tunisian coast. The parameters reported in this study contribute to a better knowledge of this species, but other parameters as total and natural mortality have to be studied to propose a rational management of the fishing stock in Tunisia.

\section{REFERENCES}

Bagenal T.B., Tesch F.W. 1978. Age and growth. Pp.101136. In: Bagenal T. (ed.) Methods for assessment of fish Production in fresh waters. IBP Handbook No. 3. Blackwell Scientific Publications, Oxford, UK.

Benghali S.M.A., Mouffok S., Kherraz A., Boutiba Z. 2014. Some aspects on the reproductive biology of greater forkbeard Phycis blennoides (Brünnich, 1768) in western Algerian coasts (Osteichthyes, Gadidae). International Journal of Research and Reviews in Applied Sciences 19 (3): 199-206.

Bernard D.R. 1981. Multivariate analysis as a means of comparing growth in fish. Canadian Journal of Fisheries and Aquatic Sciences 38 (2): 233-236. DOI: $10.1139 / \mathrm{f} 81-030$

Bilge G. 2013. Otolith size-fish size relations in the jewel lanternfish Lampanyctus crocodilus (Actinopterygii: Myctophiformes: Myctophidae), from deepwater environment of the southern Aegean Sea. Acta Ichthyologica et Piscatoria 43 (4): 293-296. DOI: 10.3750/AIP2013.43.4.05

Bolger T., Connolly P.L. 1989. The selection of suitable indices for the measurement and analysis of fish condition. Journal of Fish Biology 34 (2): 171-182. DOI: $10.1111 /$ j.1095-8649.1989.tb03300.x

Bouhlel M. 1979. Les Gadidés des côtes Tunisiennes: Systématique, répartition et associations écologiques. Bulletin de l'Institut National Scientifique et Technique d'Océanographie et de Pêche de Salammbô 6: 5-40.

Campillo A. 1992. Les pêcheries françaises de Méditerranée. Synthèse des connaissances. IFREMER/ DRV.92.019/RH. Sète, France.

Table 4

Biogeographic comparison of von Bertalanffy growth function parameters and growth performance index $\left(\Phi^{\prime}\right)$ of Phycis blennoides

\begin{tabular}{lcrrrrrl}
\hline \multicolumn{1}{c}{ Area of study } & Sex & $\begin{array}{r}\mathrm{TL}_{\infty} \\
{[\mathrm{cm}]}\end{array}$ & $\begin{array}{c}K \\
{\left[\text { year }^{-1}\right]}\end{array}$ & $\begin{array}{c}t_{0} \\
\text { [year] }\end{array}$ & $n$ & $\Phi^{\prime}$ & Reference \\
\hline N Aegean Sea & $\mathrm{T}$ & 65.8 & 0.128 & -1.01 & 850 & 2.74 & Petrakis and Papaconstantinou (1992) \\
N and NW Iberian & $\mathrm{M}$ & 54.9 & 0.217 & -0.663 & 237 & 2.82 & Casas and Piñeiro (2000) \\
Peninsula (Atlantic) & $\mathrm{F}$ & 113.3 & 0.0886 & -0.556 & 516 & 3.06 & \\
& $\mathrm{~T}$ & 112.7 & 0.0896 & -0.518 & 918 & 3.06 & \\
Strait of Sicily & $\mathrm{M}$ & 47.1 & 0.38 & -0.03 & - & 2.93 & Ragonese et al. (2004) \\
& $\mathrm{F}$ & 68.1 & 0.22 & -0.15 & - & 3.01 & \\
Gulf of Tunis & $\mathrm{M}$ & 44.74 & 0.313 & -1.210 & 67 & 2.79 & Presently reported study \\
& $\mathrm{F}$ & 57.17 & 0.193 & -1.578 & 342 & 2.80 & \\
& $\mathrm{~T}$ & 65.73 & 0.134 & -2.050 & 409 & 2.76 & \\
\hline
\end{tabular}

$\mathrm{TL}_{\infty}=$ asymptotic length, $K=$ growth coefficient, $t_{0}=$ theoretical age at zero length, $n=$ sample size, $\Phi^{\prime}=$ growth performance index (values from the published data were calculated by the present authors), $\mathrm{M}=$ males, $\mathrm{F}=$ females, $\mathrm{T}=$ total (both sexes). 
Carpentier A., Dufor J.L., VerinY. 1991. Techniques de lectures des otolithes de gadidés en coupe fines, extension à d'autres espèces. Pp. 59-70. In: Bagliniere J.L, Castanet J., Conand F., Meunier F.J. (eds.) Tissus durs et âge individuel des vertébrés. Collection Colloques et Séminaires ORSTOM-INRA, Paris, France.

Casas J.M., Piñeiro C. 2000. Growth and age estimation of greater fork-beard (Phycis blennoides Brünnich, 1768) in the north and northwest of the Iberian Peninsula (ICES Division VIIIc and IXa). Fisheries Research 47 (1): 19-25. DOI: $10.1016 / \mathrm{S} 0165-7836(00) 00108-9$

Cohen D.M., Inada T., Iwamoto T., Scialabba N. 1990. Gadiform fishes of the world (Order Gadiformes). An annotated and illustrated catalogue of cods, hakes, grenadiers and other gadiform fishes known to date. Book series: FAO Fisheries Synopsis, Vol. 125 (10).

Costa Abecasis A.R., Canha A., Reis D., Rui Pinho M., Gil-Pereira J. 2009. Age and growth of the forkbeard Phycis phycis (Gadidae) from the Azorean Archipelago, north Atlantic. Journal of Marine Biology Association of the United Kingdom 89 (3): 629-633. DOI: $10.1017 / \mathrm{S} 0025315409002598$

Deree H.L. 1999. Age and growth, dietary habits, and parasitism of the fourbeard rockling, Enchelyopus cimbrius, from the Gulf of Maine. Fishery Bulletin 97 (1): 39-52.

Dulčić J., Kraljević M. 1996. Weight-length relationships for 40 fish species in the eastern Adriatic (Croatian waters). Fisheries Research 28 (3): 243-251.

DOI: 10.1016/0165-7836(96)00513-9

Filiz H., Bilge G. 2004. Length-weight relationships for 24 fish species from the north Aegean Sea, Turkey. Journal of Applied Ichthyology 20 (5): 431-432. DOI: $10.1111 / \mathrm{j} .1439-0426.2004 .00582 . \mathrm{x}$

Fiorentino F., Gancitano S., Giusto G.B., Rizzo P. 2003. Assessing longevity of gadoids in the Strait of Sicily on the basis of otolith reading. Biologia Marina Mediterranea 10 (Suppl. 2): 814-818.

Fischer W., Schneider M., Bauchot M.L. 1987. Fiches FAO d'identification des espèces pour les besoins de la pêche (Révision 1). Méditerranée et mer Noire. Zone de pêche 37. Vol. 2. Vertébrés, FAO, Rome.

Froese R. 2006. Cube law, condition factor and weightlength relationships: History, meta-analysis and recommendations. Journal of Applied Ichthyology 22 (4): 241-253.

DOI: $10.1111 / \mathrm{j} .1439-0426.2006 .00805 . \mathrm{x}$

Froese R., Tsikliras A.C., Stergiou K.I. 2011. Editorial note on weight-length relations of fishes. Acta Ichthyologica et Piscatoria 41 (4): 261-263. DOI: 10.3750/AIP2011.41.4.01

Gallardo-Cabello M. 1986a. Análisis de los hábitos alimenticios de la brótola Phycis blennoides (Brunnich, 1768) en el Mediterráneo occidental (Pisces: Gadidae). Anales del Instituto de Ciencias del Mar y Limnología 13 (2): 173-186.
Gallardo-Cabello M. 1986b. Determinación de la edad de la brótola Phycis blennoides (Brünnich, 1768) en el Mediterráneo occidental (Pisces: Gadidae). Anales del Instituto de Ciencias del Mar y Limnología 13 (2): 207-222.

Gallardo-Cabello M., Gual-Frau A. 1984. Consideraciones bioecológicas durante el crecimiento de Phycis blennoides (Brunnich, 1768) en el Mediterráneo Occidental (Pisces: Gadidae). Anales del Instituto de Ciencias del Mar y Limnología 11 (1): 225-238.

Gordon J.D.M., Merrett N.R., Haedrich R.L. 1995. Environmental and biological aspects of slopedwelling fishes of the north Atlantic. Pp: 1-26.

DOI: 10.1007/978-94-015-8414-2_1. In: Hopper A.G. (ed.) Deep-water fisheries of the North Atlantic Oceanic Slope. NATO ASI Series Vol. 296.DOI: 10.1007/978-94-015-8414-2

Karakulak F.S., Erk H., Bilgin B. 2006. Lengthweight relationships for 47 coastal fish species from the northern Aegean Sea, Turkey. Journal of Applied Ichthyology 22 (4): 274-278. DOI: $10.1111 /$ j.1439-0426.2006.00736.x

Knight W. 1968. Asymptotic growth: An example of nonsense disguised as mathematics. Journal of the Fisheries Research Board of Canada 25 (6): 1303-1307. DOI: 10.1139/f68-114

Le Cren E.D. 1951. The length-weight relationship and seasonal cycle in gonad weight and condition in the perch (Perca fluviatilis). Journal of Animal Ecology 20 (2): 201-219.

Lester N.P., Shuter B.J., Abrams P.A. 2004. Interpreting the von Bertalanffy model of somatic growth in fishes: The cost of reproduction. Proceedings of the Royal Society B: Biological Sciences 271 (1548): 1625-1631. DOI: $10.1098 / \mathrm{rspb} .2004 .2778$

Matarrese A., D'onghia G., Basanisi M., Mastrototaro F. 1998. Spawning and recruitment of Phycis blennoides (Phycidae) from the north-western Ionian Sea (middle-eastern Mediterranean). Italian Journal of Zoology 65: 203-209.

DOI: $10.1080 / 11250009809386814$

Mendes B., Fonseca P., Campos A. 2004. Weight-length relationships for 46 fish species of the Portuguese west coast. Journal of Applied Ichtyology 20 (5): 355-361. DOI: $10.1111 /$ j.1439-0426.2004.00559.x

Merella P., Quetglas A., Alemany F., Carbonell A.1997. Length-weight relationship of fishes and cephalopods from the Balearic Islands (western Mediterranean). Naga, the ICLARM Quarterly 20 (3-4): 66-68.

Morales-Nin B. 1992. Determinación del crecimiento de peces óseos en base a la microestructura de los otolitos. Book series: FAO Fisheries Technical Document, Vol. 322.

Morales-Nin B., Torres G.J., Lombarte A., Recasens L. 1998. Otolith growth and age estimation in the European hake. Journal of Fish Biology 53 (6): 11551168.

DOI: 10.1111/j.1095-8649.1998.tb00239.x 
Morato T., Solà E., Grós M.P., Menezez G. 1999. Diets of forkbeard (Phycis phycis) and conger eel (Conger conger) off the Azores during spring of 1996 and 1997. Arquipélago_-Life and Marine Sciences 1999 (17A): 51-64.

Morey G., Moranto J., Massuti E., Grau A., Linde M., Riera F., Morales-Nin B. 2003. Weight-length relationships of littoral to lower slope fishes from the western Mediterranean. Fisheries Research 62 (1): 89-96.

DOI: 10.1016/S0165-7836(02)00250-3

Morte M.S., Redón M.J., Sanz-Brau A. 2002. Diet of Phycis blennoides (Gadidae) in relation to fish size and season in the western Mediterranean (Spain). Marine Ecology 23 (2): 141-155.

DOI: 10.1046/j.1439-0485.2002.02763.x

Mouine N., Ktari M.H., Chakroun-Marzouk N. 2010. Age and growth of Diplodus vulgaris (Sparidae) in the Gulf of Tunis. Cybium 34 (1): 37-45.

Mouine-Oueslati N., Romdhani A., Chater I., Ktari M.H., Chakroun-Marzouk N. 2015. Age and growth of Spondyliosoma cantharus (Sparidae) in the Gulf of Tunis. Scientia Marina 79 (3): 319-324.

DOI: $10.3989 /$ scimar.04234.13A

Pallaoro A., Jardas I. 2002. Remarks on horizontal and vertical distribution of family Gadidae, Lotidae and Phycidae representatives in the eastern Adriatic. Acta Adriatica 43 (1): 3-15.

Papaconstantinou C., Caragistou E. 1989. Feeding interaction between two sympatric species Pagrus pagrus and Phycis phycis around Kastellorizo Island (Dodecanese, Greece). Fisheries Research 7 (4): 329_ 342.

DOI: $10.1016 / 0165-7836(89) 90065-9$

Pauly D., Munro J.L. 1984. Once more on the comparison of growth in fish and invertebrates. ICLARM Fishbyte 2(1): 21.

Pawson M.G. 1990. Using otolith weight to age fish. Journal of Fish Biology 36 (4): 521-531. DOI: $10.1111 /$ j.1095-8649.1990.tb03554.x

Pérez P.P., Contreras N.P. 1995. Relaciones talla-peso de peces capturados en las campañas de arrastre demersal Demersales 0993 y Demersales 0994. Informes Tecnicos. Instituto Espanol de Oceanografia No. 159.

Petrakis G., Papaconstantinou C. 1992. Some aspects of biology and population dynamics of the fork-beard (Phycis blennoides) from the N. Aegean Sea. Rapports et procès-verbaux de réunions de la Commission internationale pour l'exploration de la Mer Méditerranée 33: 304.

Quéro J.C., Porché P., Vayne J.J. 2003. Guide des poissons de l'Atlantique européen. Delachaux and Nieslé, Neuchâtel, Switzerland.
Ragonese S., Andreoli M.G., Bono G., Giusto G.B., Rizzo P., Sinacori G. 2004. Overview of the available biological information on demersal resources of the Strait of Sicily. MedSudMed Technical Documents 2: $67-74$

Ricker W.E. 1975. Computation and interpretation of biological statistics of fish populations. Bulletin of the Fisheries Research Board of Canada No. 191.

Ross R.M. 2005. Use of fish-otolith-length regressions to infer size of double-crested cormorant prey fish from recovered otoliths in Lake Ontario. Northeastern Naturalist 12 (2): 133-140. DOI: 10.1656/1092-6194(2005)012[0133: UOFRTI]2.0.CO;2

Rotllant G., Moranta J., Massuti E., Sarda F., MoralesNin B. 2002. Reproductive biology of three gadiform fish species through the Mediterranean deep-sea range (147-1850 m). Scientia Marina 66 (2): 157-166.

Sartor P., Biagi F. 1992. Feeding of Phycis blennoides (Brünnich, 1768) in the northern Tyrrhenian Sea: A preliminary note. Rapports et procès-verbaux de réunions de la Commission internationale pour l'exploration de la Mer Méditerranée 33: 310.

Sartor P., Biagi F., Mori M. 1993. Feeding habits and trophic relationships in Phycis blennoides (Brünnich), Lepidorhombus boscii (Risso) and Helicolenus dactylopterus (Delaroche) (Pisces, Osteichthyes) in the Northern Tyrrhenian Sea. Biologia Marina suppl. al Notiziario S.I.B.M. 1: 161-166.

Sorbe J.C. 1977. Régime alimentaire de Phycis blennoides (Brunnich 1768) dans le Sud du golfe de Gascogne. Revue des Travaux de l'Institut des Pêches Maritimes 41 (3): 271-281.

Sparre P. 1987. A method for the estimation of growth, mortality and gear selection/recruitment parameters from length frequency samples weighted by catch per effort. Pp. 75-102. In: Pauly D., Morgan G.R. (eds.) Length-based methods in fisheries research. ICLARM Conference Proceedings Vol. 13.

Stergiou K.I., Moutopoulos D.K. 2001. A review of length-weight relationships of fishes from Greek marine waters. Naga, The ICLARM Quarterly 24 (1-2): 23-39.

Torres M.A., Ramos F., Sobrino I. 2012. Length-weight relationships of 76 fish species from the Gulf of Cadiz (SW Spain). Fisheries Research 127-128: 171-175. DOI: 10.1016/j.fishres.2012.02.001

Whitehead P.J.P., Bauchot M.-L., Hureau J.-C., Nielson J., Tortonese T. 1986. Fishes of the North-eastern Atlantic and the Mediterranean. UNESCO, Paris.

Zar J.H. 1999. Biostatistical analysis. Prentice-Hall, Upper Saddle River NJ, USA.

Received: 15 September 2015 Accepted: 22 March 2016 Published electronically: 31 March 2016 